\title{
Globalization of EU Trade Policy in the COVID- 19 Era
}

\author{
Vladimír Müller, ${ }^{*}$ and Peter Terem ${ }^{1}$ \\ ${ }^{1}$ Matej Bel University, Faculty of Political Science and International Relations, Department of \\ International Relations and Diplomacy, Kuzmányho 1, 97401 Banská Bystrica, Slovakia
}

\begin{abstract}
.
Research background: The COVID-19 pandemic has changed the shape of economic globalization as well as the position of world trade within it. Nation states and several customs unions will have to update their trade policy accordingly to the changing situation. The need for trade policy update is especially related to the EU as one of the most important actors in the world economy.

Purpose of the article: This article deals with the priorities of EU trade policy during the presence of the COVID-19 pandemic. The authors assess what kind of changes occurred to EU's trade policy during the first eight months (February to September 2020) since the outbreak of the COVID-19 in Europe. Furthermore, the authors also assess the penetration of unusual protectionist measures into the practical execution of EU's trade policy.

Methods: Our approach is built on a content analysis of various trade policy documents from EU and WTO. In this undertaking we also critically reflect on specific trade policy measures already adopted by the European Commission since the global outbreak of COVID-19.

Findings \& Value added: The article aims to be one of the first of its kind to analyze the changes caused by COVID-19 to the formation of EU trade policy. The paper concludes that during the first eight months of the pandemic, the EU trade policy followed the liberal path and protectionist measures were applied scarcely. However, in the future, EU will have to deal with increasing protectionist pressures from both internal and external environment.
\end{abstract}

Keywords: COVID-19; Economic Globalization; EU Trade Policy; Protectionism

JEL Classification: $F 13 ; F 15$

\footnotetext{
*Corresponding author: vladimir.muller@umb.sk
} 


\section{Introduction}

The European Union's trade policy has recently been going through a number of changes. During the last ten years, the EU has undertaken a significant effort to be the one of the major contributors to the expansion of free trade in the world economy. EU's trade negotiators concluded several free trade agreements with important players within the multilateral trade system (e.g. Korea, Canada, Japan); with the EU nowadays pursuing the finalization of a plethora of additional free trade agreements (e.g. with Indonesia, Australia, New Zealand). Besides, EU has always been one of the major promoters of establishing clear trade rules within the World Trade Organization, as well as modernizing the WTO.

However, this ongoing development may soon find itself in jeopardy. Recent changes in the multilateral trade system are putting significant pressure on the EU to adopt a more protectionist attitude in its trade policy. With some of the pressure steaming from the US trade policy under the Donald J. Trump administration which is inter alia marked by setting up trade barriers [1]. Another source of the pressure comes from the increased politicization of EU trade negotiations caused by excessive public interest into the TTIP and CETA negotiations [2]. Politicization has a potential to shift trade policy towards more protectionist preferences and limit the EU's ability to successfully conclude its free trade agreements and hence further liberalize its foreign trade [3].

Moreover, 2020 was marked by the global outbreak of the COVID-19 pandemic which is the first big pandemic that has struck the world economy during such a high level of globalization. COVID-19 proved to be highly effective in spreading due to its ability to be transmitted by asymptomatic people. This situation makes tracking the spread of the virus highly difficult. Various governments have therefore reacted by imposing lockdowns. These are however damaging their domestic economies and the growth of the international trade. A high number of companies suffer from negative economic outcomes which also reinforces the pressure on governments to impose protectionist measures that will avert the existential problems of home enterprises. It has been proved that despite the negative experiences from the 1930's economic crisis, governments can in certain cases be pushed to adopt protectionist measures $[4,5]$. However, during the economic crisis which started in 2008, the European Union did not follow the protectionist path [6].

Therefore, the main aim of this paper is to assess what kind of changes have occurred to EU's trade policy during the first eight months (February to September 2020) of the COVID-19 pandemic in Europe. The authors also try to assess the penetration of unusual protectionist measures into the practical realization of EU's trade policy.

\section{Methods}

In our paper we analysed major events related to the EU trade policy that happened from $1^{\text {st }}$ February 2020 until the $15^{\text {th }}$ September 2020. The time horizon reflects the period beginning with the first confirmed cases of community spreading of COVID-19 in Europe until the finalization of the paper in mid-September.

The authors tried to achieve the aim of the paper through the examination of two specific areas. Firstly, we performed a descriptive analysis of major EU trade policy milestones whose implications have had a global impact in the selected time period. These included policy decisions that contained a policy dimension and were not based only on data (other than the imposition of anti-dumping duties and anti-subsidy duties that are based on the results of an investigation). Every identified decision was examined whether it contributed to elimination of existing trade barriers or contributed to creation of new trade barriers. If a specific decision has eliminated or decreased the amount or level of trade barriers, it was marked as liberalizing. If a specific decision has raised a trade barriers or 
caused a delay in lowering them, it was marked as protectionist. If there was no impact on trade barriers, it was marked as neutral. We also indicated whether a specific decision was directly influenced by the COVID-19 pandemic. This analysis was based on a review of official documents, press releases and press conferences of the European Commission primarily from the DG Trade.

For the analysis of the second area we use notifications of the EU to the WTO about trade measures adopted due to COVID-19. Whereas one of the main principles of functioning of the WTO is transparency, every member must submit a notification to the WTO about any trade measures adopted due to the pandemic. We analysed relevant notifications coming from the EU during the selected time period and resulting measures affecting trade in goods and services. For every trade measure we stated whether it was liberalizing, protectionist or neutral using the same process as in the first examined area. For this content analysis we used the publicly available information from the WTO website [7] dedicated to the special trade measures adopted by member states due to the COVID-19 pandemic.

The authors do not try to come to an ultimate conclusion whether COVID-19 increased the level of protectionism within the EU trade policy. Rather they seek to assess the state of play during the first eight months of the COVID-19 pandemic and identify ongoing and future trends resulting from the outbreak of the pandemic.

\section{Results}

Within the first examined area, we identified 11 major decisions related to the EU trade policy during the examined time period from $1^{\text {st }}$ February 2020 until the $15^{\text {th }}$ September 2020. These decisions are listed chronologically (Table 1) together with the indication whether the decision is protectionist or liberalizing as well as with an indication whether its implementation was caused directly by the COVID-19 pandemic. The direct COVID-19 causation, whether the causes of a specific policy decision can be dated to the time period before the outbreak of the COVID-19 pandemic, was identified by the authors through a detailed examination of available data. 
Table 1. List of major decisions related to EU trade policy since $1^{\text {st }}$ February 2020 until the $15^{\text {th }}$ September 2020

\begin{tabular}{|c|c|c|}
\hline Decision & $\begin{array}{c}\text { Protectionist/Liberalizing/ } \\
\text { Neutral }\end{array}$ & $\begin{array}{c}\text { Caused by COVID-19 } \\
\text { (Yes/No) }\end{array}$ \\
\hline $\begin{array}{c}\text { 1. Approval of EU-Vietnam } \\
\text { FTA }\end{array}$ & Liberalizing & No \\
\hline $\begin{array}{l}\text { 2. Restriction of export of } \\
\text { personal protective } \\
\text { equipment (PPE) outside } \\
\text { the EU }\end{array}$ & Protectionist & Yes \\
\hline $\begin{array}{l}\text { 3. Delay of various EU } \\
\text { trade negotiations (UK, } \\
\text { Indonesia, Australia...) }\end{array}$ & Protectionist & Yes \\
\hline $\begin{array}{l}\text { 4. Co-establishment of } \\
\text { Multiparty Interim Appeal } \\
\text { Arbitration Arrangement }\end{array}$ & Neutral & No \\
\hline $\begin{array}{c}\text { 5. Conclusion of } \\
\text { negotiations of EU-Mexico } \\
\text { FTA }\end{array}$ & Liberalizing & No \\
\hline $\begin{array}{l}\text { 6. End of restriction of } \\
\text { export of personal } \\
\text { protective equipment (PPE) }\end{array}$ & Liberalizing & Yes \\
\hline $\begin{array}{l}\text { 7. Decision on maintaining } \\
\text { safeguards to defend steel } \\
\text { industry }\end{array}$ & Protectionist & No \\
\hline $\begin{array}{l}\text { 8. Appointment of Chief } \\
\text { Trade Enforcement Officer }\end{array}$ & Neutral & No \\
\hline $\begin{array}{l}\text { 9. Decision on full } \\
\text { compliance with the WTO } \\
\text { ruling in AIRBUS case }\end{array}$ & Liberalizing & No \\
\hline $\begin{array}{l}\text { 10. Withdrawal of duty-free } \\
\text { access to EU for Cambodia }\end{array}$ & Protectionist & No \\
\hline $\begin{array}{l}11 . \text { Tariff reduction } \\
\text { agreement with the US }\end{array}$ & Liberalizing & No \\
\hline
\end{tabular}

As it is stated in Table 1, the majority of EU trade policy decisions was not caused by the COVID-19 pandemic, only three cases could be classified as such. EU trade policy experienced 5 liberalizing and 4 protectionist decisions. Two cases had to be assessed as neutral. However, it must be noted these two cases: the Co-establishment of Multiparty Interim Appeal Arbitration Arrangement and the Appointment of Chief Trade Enforcement Officer contribute neither directly to raising nor eliminating of trade barriers, though they could be assessed as liberalizing because they preserve the current multilateral trade system based on economic liberalism [8].

Second examined area deals with the trade measures notified to the WTO. In Table 2, they are listed as stated by the WTO together with the indication whether they are protectionist, liberalizing or neutral. Some measures adopted in the same sector were merged into one line for the sake of saving space in the table. 
Table 2. List of trade measures adopted by the EU due to the COVID-19 pandemic and notified to the WTO since $1^{\text {st }}$ February 2020 until the $15^{\text {th }}$ September 2020

\begin{tabular}{|c|c|c|}
\hline Measure & Source & $\begin{array}{c}\begin{array}{c}\text { Protectionist/Liberalizing/ } \\
\text { Neutral }\end{array} \\
\end{array}$ \\
\hline $\begin{array}{l}\text { Exports of personal protective } \\
\text { equipment (PPE) subject to an } \\
\text { export authorization }\end{array}$ & $\begin{array}{c}\text { WTO document } \\
\text { G/MA/QR/N/EU/4/Add. } 1 \text {; } \\
\text { Add. } 2 \text {; Add. } 3\end{array}$ & Protectionist \\
\hline $\begin{array}{l}\text { Relief from import duties and } \\
\text { VAT exemption on import of } \\
\text { goods needed to combat the } \\
\text { COVID-19 }\end{array}$ & $\begin{array}{c}\text { European Commission } \\
\text { Decisions 2020/491 and } \\
2020 / 1101\end{array}$ & Liberalizing \\
\hline $\begin{array}{l}\text { Implementation of Green } \\
\text { Lanes on borders to ensure the } \\
\text { availability of goods and } \\
\text { essential services. }\end{array}$ & $\begin{array}{l}\text { European Commission Notice } \\
\text { 2020/C } 96 \mathrm{I} / 01\end{array}$ & Liberalizing \\
\hline $\begin{array}{l}\text { Guidance on more flexible } \\
\text { usage of the public } \\
\text { procurement framework in } \\
\text { situations related to the } \\
\text { COVID-19 crisis }\end{array}$ & $\begin{array}{c}\text { European Commission } \\
\text { Communication 2020/C } 108 \\
\text { I/01 }\end{array}$ & Liberalizing \\
\hline $\begin{array}{l}\text { Guidelines for border } \\
\text { management measures }\end{array}$ & $C(2020) 1753$ final & Neutral \\
\hline $\begin{array}{c}\text { Facilitating Air Transport } \\
\text { Operations }\end{array}$ & $\begin{array}{c}\mathrm{C}(2020) 2010 \text { final ; } \\
\text { Regulation 2020/0042 } \\
\text { amending Council Regulation } \\
\text { (EEC) no 95/93 }\end{array}$ & Liberalizing \\
\hline $\begin{array}{l}\text { Guidance on customs issues } \\
\text { related to the COVID-19 } \\
\text { emergency }\end{array}$ & $\begin{array}{c}\text { DG TAXUD } \\
\text { Ref. Ares }(2020) 3120083 \text { - } \\
16 / 06 / 2020\end{array}$ & Neutral \\
\hline $\begin{array}{l}\text { Guidelines on the optimal and } \\
\text { rational supply of medicines }\end{array}$ & $\begin{array}{c}\text { European Commission } \\
\text { Communication 2020/C } 116 \\
\text { I/01 }\end{array}$ & Liberalizing \\
\hline $\begin{array}{l}\text { Screening of FDI in EU } \\
\text { companies mainly in the fields } \\
\text { of health and medical research }\end{array}$ & $\begin{array}{c}\text { European Commission } \\
\text { Communication C }(2020) 1981 \\
\text { final } \\
\end{array}$ & Protectionist \\
\hline $\begin{array}{l}\text { ECB granting temporary } \\
\text { capital and operational relief } \\
\text { for supervised banks }\end{array}$ & $\begin{array}{l}\text { ECB press releases from } \\
12 / 3 / 2020 \text { and } 20 / 3 / 2020\end{array}$ & Neutral \\
\hline $\begin{array}{l}\text { Three measures related to road } \\
\text { transport (border management, } \\
\text { waste transport, extension of } \\
\text { certificates) }\end{array}$ & $\begin{array}{c}\text { C(2020) } 1753 \text { final ; } \\
\text { Regulation (EU) 2020/698 }\end{array}$ & Liberalizing \\
\hline $\begin{array}{l}\text { Allowance for more flexibility } \\
\text { with port charges for maritime } \\
\text { transport services }\end{array}$ & Regulation (EU) 2020/697 & Liberalizing \\
\hline
\end{tabular}

One important fact is that there are two important trade measures that were shared with the WTO by the EU but were not listed on the WTO website dedicated to COVID-19. The measures in question are: the creation of temporary framework for state aid measures (protectionist) and notice on COVID-19 impact on anti-dumping and anti-subsidy investigations (neutral) [9].

If we summarize all trade measures listed above then we can conclude that three trade measures notified to the WTO were protectionist (including the temporary framework for 
state aid measures), seven measures were assessed as liberalizing and three were assessed as neutral.

\section{Discussion}

From the results stated above it would seem that the European Union has during the first eight months of the COVID-19 pandemic actively pursued a trade policy based on the neoliberal free trade paradigm, as the overall number of liberalizing trade measures in both examined areas prevails. However, such a conclusion would be hastily drawn. Within Table 1 we can identify seven major decisions $(1,4,5,7,8,9,10)$ that were the continuation of processes that have started long before the outbreak of the pandemic and would be finalized anyway.

The two protectionist decisions made because of COVID-19 (restriction of exports of PPE and the delay of EU trade negotiations) were caused primarily by health reasons and the uncertainty about the spreading of the virus. After the end of the first peak of the pandemic, restrictions were lifted, and EU trade negotiations returned to their original pace. Thus, there was no intention to protect home EU production.

The two protectionist measures not caused by COVID-19 were made under different circumstances. The withdrawal of duty-free access for Cambodia (Everything But Arms Status) was made because of serious human rights violation in the country. Therefore, the decision on maintaining safeguards to defend steel industry is the only purely protectionist major trade policy decision that was aimed at tackling the negative consequences caused by development on the steel market. This decision was a second review of a 2018 safeguard decision and even though the European Commission mentioned the direct influence of COVID-19 on its adoption [10], we traced some of the root causes to the time period before February 2020. (Paragraph 14 of [10])

Two neutral decisions: the Co-establishment of Multiparty Interim Appeal Arbitration Arrangement and the Appointment of Chief Trade Enforcement Officer are institutional and do not have any direct protectionist or liberalizing dimension. Though, they are innovative for the current EU trade policy. Both were made under the intention to preserve the functioning of the current multilateral trade system and the proper fulfilment of trade agreements.

Table 2 illustrates a very similar picture. Three protectionist measures are related to export of PPE (which is present in both presented areas), investment screening and facilitating state aid provision. All of them are purely protectionist but declared to be temporary. Restriction of exports of PPE was already lifted and the other two should be lifted soon after the end of the COVID-19 pandemic. However, the state aid provisions could in the long term cause a number of problems for the EU because they might be the subject of anti-subsidy investigations from other states.

Liberalizing measures from the Table 2 cannot be framed as a significant contribution to the liberalization of the current multilateral trade system. They are not reducing the number of trade barriers from the time before the pandemic, they are just lowering and tempering some protective measures adopted by EU member states or clarifying the changes within ordinary procedures.

Our findings mostly agree with the opinion of Jan Orbie and Ferdi de Ville presented in their policy brief [11] in which they state that EU trade policy has so far been consistent with free trade philosophy and the protectionist measures were implemented rarely. We can agree that protectionism was not the driving force of EU's trade policy during the first eight months of the pandemic. However, as the COVID-19 pandemic is not over yet, there is a significant need to conduct additional research over a longer period of time that will also consider the overall trade statistics from 2020 — these data will be available in 2021. 
However, previous evolution of the issue indicates that the COVID-19 pandemic could cause an even greater paradigmatic shift that would change the functioning of the current multilateral trade system. The EU which is seriously hit by COVID-19, will arguably speed up its efforts in the long planned economic and environmental reforms.

One of the most important reforms could be the Carbon Border Adjustment Mechanism which would impose a tax (tariff) on imports of certain products according to their carbon footprint and thus effectively ensure that production would not be relocated to countries with less ambitious climate policies. This mechanism was explicitly mentioned in the State of the Union speech of Ursula von der Leyen [12]. Previous research shows that carbon tariffs have great potential to reduce emissions but will hurt existing world trade flows [13, $14,15]$.

Another important factor is the need for stronger resilience of global supply chains. COVID-19 demonstrated that even the most advanced economies in the world are heavily dependent on imports of certain products that are produced in a small number of countries. So in a situation in which the biggest suppliers do not supply these products, the importers could find themselves facing large issues, such as it happened with the shortage of Paracetamol from India or the shortage of PPE from China [16]. Coming from this, it can be argued that the aspect of reliability of a supply chain will probably become more important than the cost efficiency within the supply chain.

These two trends could speed up the paradigmatic shift of the EU trade policy from neoliberalism and a strong endorsement of free trade towards a slightly more protectionist approach that would not be based on the protection of home production but on the environmental consideration and reliability aspects of supply chains.

\section{Conclusion}

The results of this paper show that the EU trade policy during the first eight months of the COVID-19 pandemic has not experienced a radical shift towards protectionism. Based on our results, it can be argued that most of the analysed trade policy decisions were liberalizing and contributed towards free trade promotion. We also conclude that the majority of the analysed decisions and measures have been the result of already ongoing processes and thus would by implemented anyway. During the time frame examined in this paper, the European Commission continued to act as a liberal economic actor. This can inter alia be seen in the Commission's actions undertaken against radical protectionist measures implemented by member states. However, it must be noted, that the European Commission has due to the COVID-19 also adopted a limited number of protectionist measures, but these were framed as exceptional and temporary. Nevertheless, in the near future one might expect mounting pressure on the EU to implement more protectionist measures. With the pressure being among other things the result of economic problems of domestic companies, the implementation of some kind of carbon tariffs, as well as the processes connected to strengthening the resilience of supply chains.

This paper was created within the project VEGA n. 1/0437/20 The potential and limits of the foreign policy of the Slovak Republic in the framework of the EU's external relations.

\section{References}

1. Zhou, W., Gao, H. (2020). US-China Trade War: A Way Out? World Trade Review, 19(4), 605-617.

2. Young, A.R. (2019). Two wrongs make a right? The politicization of trade policy and 
European trade strategy. Journal of European Public Policy, 26(12), 1883-1899.

3. Dür, A., Eckhardt, J., Poletti, A. (2020). Global value chains, the anti-globalization backlash, and EU trade policy: a research agenda. Journal of European Public Policy, 27(6), 944-956.

4. Viju, C., Kerr, W.A. (2012). Protectionism During Recession-Why are Trade Barriers no Longer the Preferred Policy Choice? In A. Lacob, G. A. Baskan \& H. Uzunboylu (Eds.), Proceedings of World Conference on Business, Economics and Management (BEM-2012) (pp. 1366-1370). Amsterdam: Elsevier.

5. Georgiadis, G., Gräb, J. (2016). Growth, Real Exchange Rates and Trade Protectionism since the Financial Crisis. Review of International Economics, 24(5), 1050-1080.

6. Bollen, Y., De Ville, F., Orbie, J. (2016). EU trade policy: persistent liberalisation, contentious protectionism. Journal of European Integration, 38(3), 279-294.

7. WTO (2020, September 15). COVID-19 and trade by country. WTO. https://www.wto.org/english/tratop_e/covid19_e/covid_details_by_country_e.htm?coun try=EEC\#countPropos

8. Muzaka, V., Louis Bishop, M. (2015). Doha stalemate: The end of trade multilateralism? Review of International Studies, 41(2), 383-406.

9. European Commission (2020, April 27). European Commission informs WTO on new set of coronavirus measures. EU Trade.

https://rade.ec.europa.eu/doclib/press/index.cfm?id=2140\&title=European-

Commission-informs-WTO-on-new-set-of-coronavirus-measures

10. European Commission (2020, June 1). Notification under Article 12.1(c), 12.2, 12.3 of the Agreement on Safeguards. EU Trade.

https://trade.ec.europa.eu/doclib/docs/2020/may/tradoc_158766.pdf

11. Orbie, J., De Ville, F. (2020). Impact of the COVID-19 Crisis on EU Trade Policy: Our Five Cents to the Debate. United Nations University.

http://cris.unu.edu/sites/cris.unu.edu/files/PB-20.2 - Jan Orbie and Ferdi De Ville.pdf

12. European Commission (2020, September 16). State of the Union 2020. European Commission website. https://ec.europa.eu/info/sites/info/files/soteu_2020_en.pdf

13. Larch, M., Wanner, J. (2017). Carbon tariffs: An analysis of the trade, welfare, and emission effects. Journal of International Economics, 109, 195-213.

14. Böhringer, C., Carbone, J.C., Rutherford, T.F. (2018). Embodied Carbon Tariffs. The Scandinavian Journal of Economics, 120(1), 183-210.

15. Fang, Y., Yu, Y., Shi, Y., Liu, J. (2020). The effect of carbon tariffs on global emission control: A global supply chain model. Transportation Research Part E - Logistics and Transportation Review, 133. 1-21.

16. Horner, R. (2020, May 25) The world needs pharmaceuticals from China and India to beat coronavirus. The Conversation. https://theconversation.com/the-world-needspharmaceuticals-from-china-and-india-to-beat-coronavirus-138388 